\title{
USING DIGITAL AUDIO RECORDING IN LEARNING SPEAKING
}

\author{
Tara Arsih Wijayani \\ Islamic University of Indonesia
}

\begin{abstract}
Digital Audio Recording is a media formed in CDs to enhance students' listening skill. Digital audio recording was conducted in relation to the fact that there are a lot of students who have leamed English for several years but they are still reluctant to speak. The process of using digital audio recording started with listening session to show some examples of a situational conversation and the expressions that can be used in it. The expressions were in common situations that students usually face in daily speaking English. The next steps were composing their own speaking as well exposed in the listening materials and recording their voice in a digital form using sound recording in a computer. Using digital audio recording created atmosphere of fun to the students to start speaking in English after they have got the exposure from the listening materials. The students are allowed to operate their recording and listen again to what they have produced in speaking.
\end{abstract}

Digital audio recording is an electrical or mechanical inscription and recreation of sound waves, such as spoken voice. Digital audio recording was used in this research as digital audio records in listening materials and the students' projects. Digital audio records can be kept eternally as long as they are not corrupted by virus. Other goodness of digital audio recording is it can track precisely any parts wanted by the listeners. So the teachers could easily which part was needed to repeat for some times. It made listening activities easier to conduct and clearer in quality of sounds compared to analogue one.

The events depicted the process of learning speaking in language laboratory and in the classroom and how students are learning speaking using digital audio recording. By looking into their learning and performance in speaking using digital audio recording, it can be seen how far this phenomenon affects students' language production. It would show their enjoyment in learning English and they could see their weakness in performing speaking. Students' reflection on using digital audio recording to learn speaking was to hear the students' voice on it. Teacher's voice was also used as supporting points on how this phenomenon contributes to students' performance in speaking. 
Moreover, digital audio recording helps them to know their speaking skill level and hopefully would improve their speaking ability.

The findings of the research contribute to the understanding of the phenomenon, that using digital audio recording becomes the needs and is beneficial to support students in learning a language to improve their productive skill i.e. speaking ability and performance, personally for their future careers. For the teachers, it can be beneficial to pedagogical suggestions. The findings imply suggested learning activities regarding to students' autonomy and empowerment. Eventually, the findings of this research would humbly contribute in increasing life quality in broad understanding.

Keywords: Digital audio recording, learning speaking.

\section{Introduction}

Using Digital Audio Recording for Learning Speaking was aimed to investigate the students ${ }^{\top}$ experiences in using digital audio recording in learning speaking It was to reveal the meaning of using digital audio recording within the English speaking classroom and language laboratory activities as truly experienced by students.

Working with a computer and learning using computer becomes usual daily activities and needs for many people today. Language education also tries to keep pace with the development in technology. Every school is mostly equipped with language laboratory that is used for listening activities. The language laboratory mostly also collects language learning software and listening materials that contain models and records of native speaker's audio language performance to adjust language learners with internationally used English.

Many language learners are still feeling reluctant to speak though they have learnt English for several years. It becomes my concern as this might happens as they are afraid of making mistakes in grammar and pronunciation. The other thing came into my consideration was they were still might be not sure how to say phrases or expressions in English properly and suitably. They might not sure whether the sentences they produced were grammatically correct and understandably pronounced. Those kinds of feeling during producing second language utterances cause feeling of reluctance in speaking the target language. However, there is a way to improve their speaking ability. One thing into consideration is that they need a model that can show the way to speak it in the target language and imitate it. It reminds me that listening comes before speaking. 
Language learners need a model of a target language. What I mean here is, first, they use listening materials as the model for speaking activity. Learners listen to a conversation models which is in form of digital audio records. Secondly, they compose a conversation that uses certain expressions they learn. Then, they use digital audio recorder in the computer's accessories program to record their voice in conversation they have composed previously. Listening, composing a conversation and recording the conversation processes help learners to learn and practice their productive skill, in this case speaking, through digital audio recording. Taking a model of a certain situation in to speaking activity after listening to and leam it in form of digital audio records will lead learners to try to practice speaking in English with secure feelings. In this case, students also have confidence when they have to speak, because they have listened and learned some models as examples previously. Students who have opportunity to learn and modify their output during an interaction in speaking will have a focus on forming more comprehensible utterances (Egbert and Hanson-Smith, 1999, p. 184).

Leaming a language starts with listening then imitating to what we have listened. This process follows the rule that listening comes before speaking as also known as input (Ferguson, 1971) and output (Swain, 1985). Based on the process of learning, digital audio recording in language learning might help. When people learn a language they sometimes forget what steps of learning they have been going through. Using digital audio recording in learning speaking, language learners can see and keep their conversation in language leaming in a digital audio records. It is useful as the reflection on learning, in this case on speaking skill.

Digital audio recording is a record done in a program on a computer like window media player or $\mathrm{mp} 3 / \mathrm{mp} 4$ or even quick time player and window classic. A computer has been equipped with entertainment in accessories part containing sound recorder. This sound recorder is in digital form. It allows computer users to record and reproduce sound waves such as spoken voice. There are two kinds of recording i.e. analog and digital ones. Digital form is different from analogue one. It has certain code that can track precisely on which part the person would really want to play. In digital form it is easier to track or locate the part we need to search or replay as it is in binary system. Language leamers can store their spoken voice in the digital form and play it again to listen to and reflect students' performance in practicing speaking in English. As it is stored in a record, it helps teachers to assess their students learning progress.

Hanson-Smith (2004) suggests that computer technology can provide a student the means to control their own learning, to construct meaning and to evaluate and monitor their own performance. The learning gets autonomous and 
independent in personal and time. This situation helps the students to use their time effectively as they can make their own schedule in learning. Computer will change the nature of learning by placing the power of learning more in the hands of the learner (Bruce, 1993). However, teaching and learning process (TLP) has to focus in developing an effective ways in using computers in the classroom.

The globalization helps learning through connecting with the computer programs or websites, which is why students need to adapt to the technology. It relates to how students productively express meaning. Brown (2000) says that learning can be thought of as cognitive, affective and physiological traits. These are the basic processes in leaming. They are relatively stable indicators to indicate how learners perceive, interact with and respond to their learning environment. Using computer to assist their leaming will also let students to learn individually while at the same time construct their social interaction with their classmates.

Using computer in learning a language assists and even stimulates young second language leamers in improving their skills of listening, speaking, writing, reading and also critical thinking (Cobb \& Stevens, 1996). Students will be able to learn English comprehensively. Learning a language whether it is in the classroom or in the language laboratory may make students bored with the tasks they have. However, when the classroom activity needs not only books and tasks but also involves tactical process as operating computer while recording, it can be more challenging for language learners. In learning speaking, using digital audio recording allows students to prepare their speaking activity from composing a dialogue or a short conversation and record it in the laboratory computer. The process of learning will create students' interaction, sharing-knowledge and let students be more active in their performance.

Using digital audio recording in learning speaking help teachers to maintain the class in active situation during teaching and learning process. Students have to do various kinds of activities from listening to recording. The products of those activities are kept in forms of records so that make a teacher easy to review again the students' performance. The teachers will use the records for the learning assessment. Since the performance stay the same in the record, the progress on students learning can also be evaluated as it is.

The spirit of post modem era and post colonialism teaches us that everyone has the same opportunity and rights to actualize themselves and be more selffulfilling in order to develop themselves. In teaching and learning process, teacher is no longer takes dominant role. Teacher's role is as the facilitator in a teaching and learning process. On the other hand, the students' role is more dominant in order to 
building their self-actualization. It is important as every learner is unique and individually has different character one to another. What can be done in teaching and learning process is that giving as vast opportunity as possible to learners to develop their potentials. From this point of view, I try to dig up the process of learning in the language laboratory using digital audio recording to fulfill my concern to see the students' live experience in learning speaking using digital audio recording.

My concerns are seeing language learners being able to produce a language in speaking and they feel secure when speaking. That leads me to see how using digital audio recording has created a fun classroom environment. For those reasons, I was really interested in investigating using digital audio recording in learning speaking in the language laboratory. It is to see how using recorded speaking digital media helps students to experience fun speaking classroom by previously learning from the models of djalogues and conversations in the phenomenon. Hopefully this experience will enrich students' understanding about learning English. So, in the future when they are ready to work or working in the global era, this learning experience will bring an improvement to their learning to be more autonomous and self-fulfilling.

\section{Literature Review}

The discussion is on the Constructs and Related Research. Under the Construct of two issues called digital audio recording and Learning Speaking are described to clarify the concepts used in this research. This section is divided into two parts. First, it elaborates the constructs of the research. Second, it presents a related research that is important as references and eventually, it shows the significance of this research with the current language teaching pedagogy.

There are mainly two themes: Using digital audio recording and the students' lived experience of the activities in learning speaking. Using digital audio recording in Learning Speaking is deconstructed into: 1) digital audio recording which is divided into two: 1.a) Digital Audio Records as a Model of Speaking in Target Language the target language to learn Speaking; 1.b) Digital Audio Recording as Students' Recording Projects; 2) Learning Speaking as Lived Experience.

\section{a. Digital Audio Recording}

A digital system. is system of a data technology using discrete or discontinuous values. It differs from analogue (non-digital) systems as digital 
system uses binary system. Analog system uses a continuous range of values in representing information (Tocci, 2006). Binary system in digital system helps users to get precise code track of a records. So, it is easy to trace. It represents the continuous information in codes, such as numbers or letters in form of sounds or audio or images, such as picture displays or movies.

In 1982, the compact disc brought significant improvements in the durability of recordings. However, the digital systems were resisted by piracy. It can produce perfect copies of original released recordings (H:Digital_media.htm). Digital audio recording and reproduction is an electrical or mechanical inscription and re-creation of sound waves, such as spoken voice, music, or sound effects. The two main classes of audio recording technology are analogue audio recording and digital audio recording.

In language laboratory, there are learning equipments to support students' learning activities. Personal computer is one of them. A personal computer is equipped with programs. One of them is called accessories. In the accessories we will find entertainment where sound recorder is within. This program can be used to digitally record audio messages and stored or changed in the duration depending on the needs of users. In the recording process, the person who record can listen again and again any parts they want to as it was formulated in binary system as a series representing samples of the audio signal at equal time. So, it helps a lot to listen again any parts they want to repeat in learning a language. It helps learner also to hear how well they are playing or performing during recording sessions. As they are formed in digital audio records, they can be stored forever, of course with one condition not being corrupted by virus. Virus was the major destroyer of digital records. As the nature is durable and limitless; they can be kept as a collection of series of learning English process in a Language Laboratory. In addition, it is good as a reflective learning collection.

Digital audio records can be as a model of speaking form in a target language. Digital audio recording is used as audio model for speaking class. It is a task-based listening course using cassettes or disk such as Listen for It composed by Jack C. Richards, Deborah Gordon and Andrew Harper. It contains activities for ESL listening. The listening materials contain expressions used in daily language. It has been divided into some units for a class. There are 5 units to be learned in each level. The units provide models in certain situations started from self introduction unit until making plans or arranging any events. Those help students to learn and imitate the way to use the expressions in real situations. The feeling of security in speaking of 
-students' may rise as they have the models to show how to say it in target language. From listening the models and related situations, it advocates the students to be able and understand how to speak English for practice and using it in real situations.

Digital Audio Recording can be as Students' Recording Project, done by students to fulfill the requirement in the end of semester. Students' records are the records that have been created from students' composition. The students compose a conversation as the topic given. The topics are based on the text book they have. The recording time are taken after some meetings have been finished. It can be done after 2 or 4 meetings for listening to give exposure to learners the expressions on certain situations and to rehearse some expressions that are important for the situations.

The students are confident enough in producing their speaking since previously the students have had listening time to explore the models for their speaking. As a result their compositions are easily to be made as they follow the expresions in the models.

The students' record is usually called speaking project. The project has certain points to be fulfilled. The duration at least takes $4-5$ minutes. There should be 2 or 3 students in a group and there should cover a certain situation. The points of the project help students to focus on the conversation. It also helps them to classify which expressions belong to which siturations.

\section{b. Learning Speaking as Lived Experience}

Speaking and learning speaking in a target language is different. However, they have the same natural process. Speaking comes after listening. People learn to speak because they try to imitate the sound or voice they have heard and listen. The process of using digital audio recording in leaming speaking has the same sequence as learning to speak in general. Learners or students are exposed to listening materials in form of digital audio records and from the axposure they try to produce a recording from a conversation or a dialogue they have composed. So, it can be seen that this is a kind a process of learning from listening and speaking a target language. It can become the students' lived experience that will be significant in their learning the target language.

This research is based on Max Van Manen's Structural Framework on interpreting a series of events that is experienced by the particiupants and becomes lived in their mind. I choose hermeneutics phenomenilogy as the approach to see through and interprete what actually the participants' lived experience is. Hermeneutics is considered as a theory or "technology" of 
interpretation, the interpretation of a certain event to see and to oppose the acceptance of unobservable matters. I try to see the lived experienced in Van Manen in relation to learning speaking using digital audio recording.

Lived experience is a series of events that has experienced and becomes lived as it is significant. Speaking is one of the productive skills as really the beginning to show how well we have been leaming a language. There is a process of being fluent in speaking. However, the beginning is what people say as the most difficult part. Many language learners are reluctant to speak to avoid mistakes or they do not know how to say it in target language. Using digital audio recording they can start to perform their speaking.

The approach of hermeneutic phenomenology is to listen and comprehend the lived experience. The lived experience in learning speaking in my research is learning speaking in a language laboratory using digital audio recording in a personal computer. How it helps the students in learning speaking and advocating their self confidence in speaking will be seen in the process of observation on learning speaking experience. The process of using digital audio records of listening materials, the process of students doing their tasks in speaking and the students' performance in digital audio recording is series of events to see how the experience gives significant meaning to the students in learning speaking.

Learning speaking relates to second language acquisition as people leam speaking after their listening to second language models. As this research is done in the classroom, so the area of research limited to the language laboratory. Second language acquisition classroom research concerns with how people learn languages in educational settings (Doughty, Catherine; Williams, Jessica, eds: 1998). It is also concerned with what the learners do in the classroom, in this case in the language laboratory.

From using digital audio recording in learning speaking, it helps teachers to give feedback based on the records the students have created. Corrective feedback can be directly understood by students as it happens after both teacher and students- have listened to students' record. The effectiveness of corrective feedback relates to correction whether. on accuracy on communication of meaningful content. It will lead to a correction on learner's ability to focus on corrective feedback on grammatical features, eventually.

\section{c. Related Study}

There was a study using sound recorder of an entertainment in the accessories program of a computer. It was conducted in Japan by David $E$, 
Kluge and Mathew Taylor. It focuses on Boosting Speaking Fluency through Partner Taping. It discuses-on how to give students more fluency in practice their English. The method is ${ }^{\top}$ the students are required to tape conversations outside of class every week. From the research it could be seen that the results of this "partner taping" was encouraging. The students stay in English while taping, develop greater fluency, gain hours of extra practice, maintain a concrete record of their progress, and get a sense of responsibility for their learning. The teacher also gains a better sense of the students and their language problems (Kluge \& Taylor, 1999).

\section{Discussion}

Digital audio record in listening material is usually called sound-clips (Egbert and Hanson-Smith, 1999, p.199). Sound-clips or audio stream can be provided and published by international language institutions such as Longman, Cambridge or Oxford and/or local institution such as TOEIC or even the records of the students' themselves. Digital audio records can be said as authentic. It means by using sound-clips can also be said as showing the authenticity in learning to the learners. Since learning through authentic materiais is getting closer to the real world, so the learners also experience learning how people speak in English (Ellis, 1984). They will learn certain expressions or the way they speak in certain situations. They experience the suitable expressions for the real situation.

In using digital audio recording; the role of teachers is as a facilitator while students are listening to the model and to their recording process. Teachers help them to learn some expressions in certain contexts or certain situation. It gives students more confident to produce speaking in English as they have the examples previously. Further, they are using the records as their model to make a dialogue, pair or group conversation and a monologue in classroom activities. The record is as the project of the learning process and the recorded performance would be listened again by the students to give a reflection to them from what they have been performed. It is very useful for their self-improvement to master speaking.

There are some models of situations in the records which are close to the real world situation which may be faced by students when they have a real life communication. Therefore, recorded speaking using digital audio recording is advocating the students to get more sufficient knowledge of an experience in learning speaking and moreover it plays an important role to advocate student in preparing thenselves to face the real world communication. 
Giving correction after listening to the record they made would give a circumstance where students feel responsible and pay attention on what they have done in learning process. As Lazaraton (2001: p.108) mentions that one of the most recent trends in oral skills pedagogy is by the emphasis on letting students analyze and evaluate the language that they or others have produced or performed. While correcting and analyzing what they have learned with peers will give a feeling of secure to the students. It may happen as students learn with the same peers who have more or less the same competence and the same ability level.

Listening skill is part of communication skills. Therefore, further in the future, after finishing their senior high school level, students are facing the real English communication in the next education level at university. They might study in Indonesia where there are a lot of handbooks written in English or study abroad where, in addition, they have to use their communication skills in English as well. That is why they need to be reinforced to master English in communication. As what Allen regards that language as an important communication aspect of study subjects (Swales, 1998: 74). Therefore, learning English as communication skills is important.

Particularly, I see that students likely encounter problems that do not merely come from the materials, but also from their communication skills, in this case the listening and speaking skills. My experience as an English teacher, I usually find students who have problems in speaking. They usually ask me almost similar questions like: "How to master Speaking in English?", "Why my English is not yet developed?", "Why still I can't speak in English thou I have learnt it since elementary school?" Of course I do not know the reasons. However, I ask them further how often they listen people speak in English and how often they practice speaking. The answers they give to me are mostly about the same. They seldom listen to people speaking English nor speak in English. They add also that when they start to speak English they are afraid to make mistakes. Further I ask them how you will be improved and see your weakness if you never try to speak in order to avoid making mistakes. Then I can guess that they will give me their special grins.

To be grammatically wrong in speaking is tolerable as long as the message delivered is understood that is what I always say to them to start listening and speaking from now, and think later about the mistakes. However, having a model in how to say this or that in a second language is important for students to start their speaking. The models given in recorded speaking digital media is helping them a lot in arranging a dialogue or making a conversation while they also learn the grammar patterns and useful expressions in certain situations. It will help the students to know how to speak in English way and not speak English from 
translating Indonesian expressions through word by word translation. The unity and the continuity of a dialogue or a conversation are what the students need to understand also.

The role of digital audio recording in learning speaking is giving the students the meaning of the students' lived experience in leaming speaking in enhancing student's speaking ability. As a result, hopefully digital audio recording would provide a better understanding of the teaching and learning experience in speaking and doing tasks of laboratory activities.

\section{Conclusions}

Using digital audio recording in leaming speaking is to enhance students speaking skill. Leaming Speaking aims at giving speaking models to language learner to facilitate them in leaming speaking. It is formulated to encourage learners to be brave to speak through listening to speaking models in daily situations faced in English. This helps students to speak English in a secure feeling as they have listened previously the expressions in the conversation.

From the students' point of view, the programs aimed at assisting them with the ability to listen the digital audio recorded listening materials in situational daily English conversation. It would be able to help the students to adjust their listening and their understanding in spoken English. They could listen some times the expressions and they know how and when to use them. After certain times in listening the digital audio recorded listening materials in situational daily English conversation, the students could broaden their knowledge and horizon related to the language they use so that they could create their own conversation related to the situation. Further, they can speak English with the global world.

From the teachers' point of view, the program motivated teachers to be the facilitator in the classroom. They could give instructions and at the same time motivate the students to be more active in their listening and more creativity in composing their own conversations. It would be fine if the instructions are given in both in Indonesian language and in English as far as the class are active and the students are creative. The program itself was prepared by two parties the school and an English College to get a better teaching for encouraging students to be creative in learning English. It can be shown from their assignments called projects. It is focussed on the verbal psycho-motoric language competence so that the students are well prepared and can compete well in the global competition with their English ability. 
It needed mutual collaboration among the school, the teachers and the students to achieve the goals. The school had a willingness to create a new way in teaching learning process by involving the third part to assist teaching and leaming process. Teachers in charge were demanded to keep motivating students to be engaged with the activities prepared for the program. They should get involved to the activities as well as the projects. The students responded to the program well by followint teaching and leaming process as well as accomplishing the projects. The whole process should be accomplished by the participation of the school, the teachers and the students. The initial process was a kind of surprise of the conventional teaching and learning process as this program was inserted in the school hours. It needed a great power to achieve the goal. However, after two years in the implementation, this program could let the students realize that they need to master English to compete in the global world. To students, in the beginning the program looked difficult to follow as they had to listen more and more during the class. They were used to listen to teacher's explanation and do the exercise afterwards. However, in this program they should listen to digital audio recording that expose daily situational English. After listening, they should memorize the expressions that could be useful for them in composing their conversations.

The program became more meaningful to them as they felt they had made better improvement in their listening as well as in speaking. By joining the Creative English Program, students might get bigger chance to be better listener of the target language and learn how to use the expressions. Further they could learn how to say appropriate expressions for certain situations. So, in the future, they will speak English more relaxed and are not worried with things like making mistakes or missing the pronunciation. Engaging in this program would be helpful for the students to communicate in English with the global world.

The program goals would be meaningful to the teachers, in terms of self encouragement to teach and give instruction creatively in teaching English in a classroom. The activities are not giving instruction and doing exercise only, but also involve the students in listening, group discussion. Teachers also helped students in preparing their composition and giving feedback on the students' works or projects. The goals in giving assignments of digital audio recording as their project could lead the students to be more autonomous and excellent in taking responsibility of their work or assignments addressed to them in the future. They learn how to engage with the activities in the classroom as well as to accomplish their projects as their responsibilities.

In teaching and leaming process, teachers made a great effort to use English as the medium of their instruction. However, using switching code like 
using bahasa Indonesia was used in the instruction to strengthen the topic they had to focus, in which the process of teaching and learning occured. In other words, in this case, English was a classroom language. The least to use bahasa Indonesia the more exposure of English to the students in the sense that it would encourage them in being active with English instruction.

The classroom atmosphere was fun as students and teachers dealt with various activities. They had listening session, doing exercise and discussion. Especially when they came to the time of recording their projects, the discussions of teachers and students were getting intensive. It happened especially in the last 10 15 minutes. The discussion was both in English and Bahasa Indonesia. It was to avoid misunderstanding and mistakes in doing the project and related to some tips to prolong their conversation. Teachers' and students' involvement in discussing the project could be seen obviously in this finishing project event.

The process of Creative English Program gave certain meanings both to teachers and students. To teachers, it gave an opportunity to be autonomous in the instruction and demanded more creativity to be fulfilled as using digital audio recorsing in teaching speaking went through some steps of teaching. To students the process of learning speaking using digital audio recording gave meanings in the sense that the students would face high challenge such as listening spoken English, the assignment given, and the high standard of minimum mastery that could be shown from the requirements of the projects. Those would lead the students to be autonomous and self-fulfilling people because the effort they made needed a responsibility. Both teachers and students could build their competency and develop their capability during discussions in the process of teaching and learning. They leam and complete each other to empower themselves.

Using digital audio recording was proved that it was good to assist the improvement of students' ability in speaking, educators and teacher can use this kind of program in their teaching or even develop more interactive teaching for active teaching and learning process. It can also be applied to contribute to the students' low achievement. Such phenomena can be further investigated to reveal what actually occurs in world realities of educational field.

\section{References}

Ashmore, Malcolm and Darren Reed. 2000. 'Innocence and Nostalgia in Conversation Analysis: The Dynamic Relations of Tape and Transcript', Forum Qualitative Sozialforschung / Forum: Qualitative Social Research 1(3). Available at: http:// qualitative-research.net/fqs/fqs-eng.htm. 
Bismoko, J. 2007. Foundation of research in english language studies and social sciences. Yogyakarta: Graduate Program in English Studies Sanata Dharma University (for internal use only). .

Brown, H.D. 2000. Styles and Strategies. In Principles of Language Learning and Teaching: Fourth Edition. Longman: New York.

Brumfit, Christopher. 2001. Individual Freedom in Language Teaching: Helping Leainers to Develop a Dialect of Their Own. Oxford: Oxford University Press.

Cobb, T., Stevens, V. 1996. Computer assisted development of spoken language skills. In M. Pennington (Ed.), The Power of CALL. Houston: Athelstan Publications.

Cohen, Louis, Lawrence Manion \& Keith Morrison. 2003. Research method in education (fifth edition). London \& New York: Routledge.

Cresswell, J.W. 2007. Qualitative inquiry \& research design : Choosing among five approaches (2nd Edition). London: SAGE Publication Inc.

Creswell, J. W. 2003. Research design: Qualitative, quantitative, and mixed methods approaches. $2^{\text {nd }}$ ed. London: Sage Publication, Inc.

Doughty, Catherine. , Williams, Jessica, eds. 1998. Focus on Form in Classroom Second Language Acquisition. Cambridge: Cambridge University Press.

Dudeney, G. 2001. The Internet and the Language Classroom. Cambridge: Cambridge University Press.

Egbert, Hanson-Smith, E. 1997. Technology in the classroom: Practice and promise in the 21st century. TESOL Professional Papers (Online). Ret i e ved Nov $13 \mathrm{th}, 2004$ from, http://www.tesol.org/s_tesol/sec_document.asp

Ellis, Rod. 2004. Understanding Second Language Acquisition. New York: Ox ford Universtity Press.

Ferguson, C. A. 1971. "Contrasting Patterns of Literacy Acquisition in a Multilingual Nation." In Language Use and Social Change, edited by W. H. Whiteley. London: Oxford University Press. 234-253.

Gass, S., Mackey, A., \& Ross-Feldman, L. 2005. Task-based Interactions in Classroom and Laboratory Settings. Language Learning, 55, 575-611.

Hanson-Smith, E. 1997. Technology in the classroom: Practice and promise in the 21st century. TESOL Professional Papers (Online). Retrieved Nov 13th, $2004 \mathrm{from}$, http:/Www.tesol.org/s tesol/sec document.asp 
Holliday, Adrian. 2002. Doing and writing qualitative research. London: Sage Publications.

Homby, A. S. 1995. Oxford Advance Learner's Dictionary. 5th Edition. Oxford: Oxford University Press.

Patton, M.Q. 2002. Qualitative research \& evaluation methods. $3^{\text {td }}$ ed. London: Sage Publication, Inc.

Richard, J. C, Gordon, D.,Harper, A. 1995. Listen for It . 2nd edition. London: Oxford University Press, USA; (January 5, 1995).

Richards, Keith. 2003. Qualitative inquiry in TESOL. New York: Palgrave Macmillan.

Lazaraton, Anne. 2002. (p.108). A Qualitative Approach to the Validation of Oral Language Tests. Cambridge University Press

Lazaraton, Anne. 2003. Incidental displays of cultural knowledge in the nonnative English speaking teacher (NNEST) classroom: TESOL Quarterly, 37, 213245.

Marcus Deininger, Kurt Schneider. 1994. Teaching Software Project Management by Simulation - Experiences with a Comprehensive Model, Conference on Software Engineering Education (CSEE).

Merriam, S.B. \& Associates. 2002. Qualitative research in practice: Examples for discussion and analysis. San Fransisco: Jossey-Bass. 